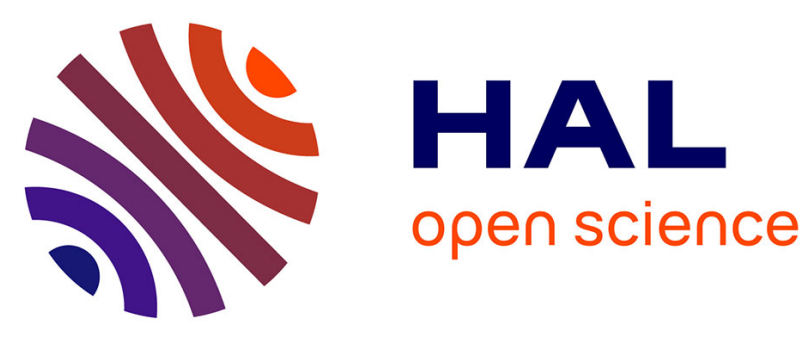

\title{
Vaginal Neoplasia Induced by an Unusual Papillomavirus Subtype in a Woman with Inherited Chromosomally Integrated Human Herpesvirus Type 6A
}

Maxime Pichon, Alexandre Gaymard, Karine Lebail-Carval, Emilie Frobert, Etienne Beaufils, Gautier Chene, Massimo Tommasino, Bruno Lina, Pascal Gaucherand, Agnès Gautheret-Dejean, et al.

\section{To cite this version:}

Maxime Pichon, Alexandre Gaymard, Karine Lebail-Carval, Emilie Frobert, Etienne Beaufils, et al.. Vaginal Neoplasia Induced by an Unusual Papillomavirus Subtype in a Woman with Inherited Chromosomally Integrated Human Herpesvirus Type 6A. Gynecologic and Obstetric Investigation, 2017, 82, pp.307 - 310. 10.1159/000470907 . hal-03591629

\section{HAL Id: hal-03591629 \\ https://hal.science/hal-03591629}

Submitted on 4 Mar 2022

HAL is a multi-disciplinary open access archive for the deposit and dissemination of scientific research documents, whether they are published or not. The documents may come from teaching and research institutions in France or abroad, or from public or private research centers.
L'archive ouverte pluridisciplinaire HAL, est destinée au dépôt et à la diffusion de documents scientifiques de niveau recherche, publiés ou non, émanant des établissements d'enseignement et de recherche français ou étrangers, des laboratoires publics ou privés. 
Gynecologic and

Obstetric Investigation
Received: November 14, 2016

Accepted after revision: March 13, 2017

Published online: April 6, 2017

\section{Vaginal Neoplasia Induced by an Unusual Papillomavirus Subtype in a Woman with Inherited Chromosomally Integrated Human Herpesvirus Type 6A}

Maxime Pichon ${ }^{a, b}$ Alexandre Gaymard ${ }^{a, b}$ Karine Lebail-Carval ${ }^{c}$ Emilie Frobert ${ }^{a, b}$

Etienne Beaufils $^{d}$ Gautier Chene $^{d}$ Massimo Tommasino ${ }^{e}$ Bruno Lina $^{a}, b$

Pascal Gaucherand $^{d}$ Agnès Gautheret-Dejean ${ }^{g}$, $h$ Pascale Bonnafous ${ }^{h}$

Tarik Gheit $^{\mathrm{e}}$ Annie Buenerd ${ }^{f}$ Gery Lamblin ${ }^{c}$ Yahia Mekki ${ }^{\mathrm{a}}$

a Laboratoire de Virologie, Institut des Agents Infectieux, CBN, Groupement Hospitalier Nord, b Univ Lyon, Virpath, CIRI, INSERM U1111, CNRS UMR5308, ENS Lyon, Université Claude Bernard Lyon 1, 'Department of Gynecology Surgery, and ${ }^{\mathrm{d}}$ Department of Gynecology and Obstetrics, Hospices Civils de Lyon, Hôpital Mère-Enfant, ${ }^{\mathrm{e}}$ Infections and Cancer Biology Group, International Agency for Research on Cancer, and ${ }^{\mathrm{f} C y t o l o g y}$ and Pathology Department, CBPE, Groupement Hospitalier Est, Lyon, ${ }^{9}$ AP-HP, Hôpitaux Universitaires La Pitié Salpêtrière-Charles Foix, Service de Virologie, and h Sorbonne Universités, UPMC Univ Paris 06, CIMI-Paris UMRS CR7, Inserm U1135, PVI Team, Paris, France

\section{Established Facts}

- Human papillomaviruses (HPV) constitute a very heterogeneous family associated with cellular-proliferation pathologies.

- Systematic screening is recommended to diagnose cervical cancer. Cellular atypias were clearly associated with HPV infections of epithelial cells.

- Human herpesvirus type 6 (HHV6) could be integrated in cell genome and transmitted from parents to children.

\section{Novel Insights}

- HPV-4 was not known to induce severe neoplasia, especially in the genital tract of women.

- Inherited Chromosomally Integrated HHV-6A (iciHHV-6A) associated to low-risk HPV could be linked to tumoral development.

\section{Keywords}

Human papillomaviruses · Inherited chromosomally integrated HHV-6A · Low-grade SIL · High-grade SIL · Vaginal intra-epithelial neoplasia · Genital cancer

\begin{abstract}
We describe here a case of high-grade vaginal squamous lesion in a 54-year-old woman with a papillomaviruses (HPV) genital infection that developed from a cervical low-grade
\end{abstract}

\section{KARGER}

(C) 2017 S. Karger AG, Basel

E-Mail karger@karger.com

www.karger.com/goi
Maxime Pichon

Department of Virology

Infectious Agents Institute

FR-69372 Lyon (France)

E-Mail Maxime.pichon01@chu-lyon.fr 
squamous intraepithelial lesion (SIL) to a high-grade SIL (H$\mathrm{SIL}$ ) on cytological examination. A colposcopy exam led to the detection of suspect vaginal lesions with granulomatous infiltrations, which were classified as a Vaginal Intra-Epithelial Neoplasia grade 2 after pathologists' analyses. After a laser vaginal surgery and a loop excision of the transformation zone, the analyses of the anatomical pieces using a nearcomplete HPV screening panel revealed an HPV-4 infection that was not detected before in cervical smears. This HPVinfection is associated with a high human herpesvirus type $6 \mathrm{~A}(\mathrm{HHV}-6 \mathrm{~A})$ viral load in the same anatomical piece. The presence of an inherited chromosomally integrated HHV-6A (iciHHV-6A) was proved in this patient by real-time polymerase chain reaction on hair follicles and nail. This case suggests reconsidering both the benign nature of low-grade lesions in the female genital tract and the well-known "good" prognosis of low-risk HPV infection, especially when iciHHV-6A is diagnosed. This clinical course insists on the benefits of the multiplex panel use or global sequencing in order to optimize biological testing sensitivity, and so enhance clinical management of infection-induced neoplasia.

(c) 2017 S. Karger AG, Basel
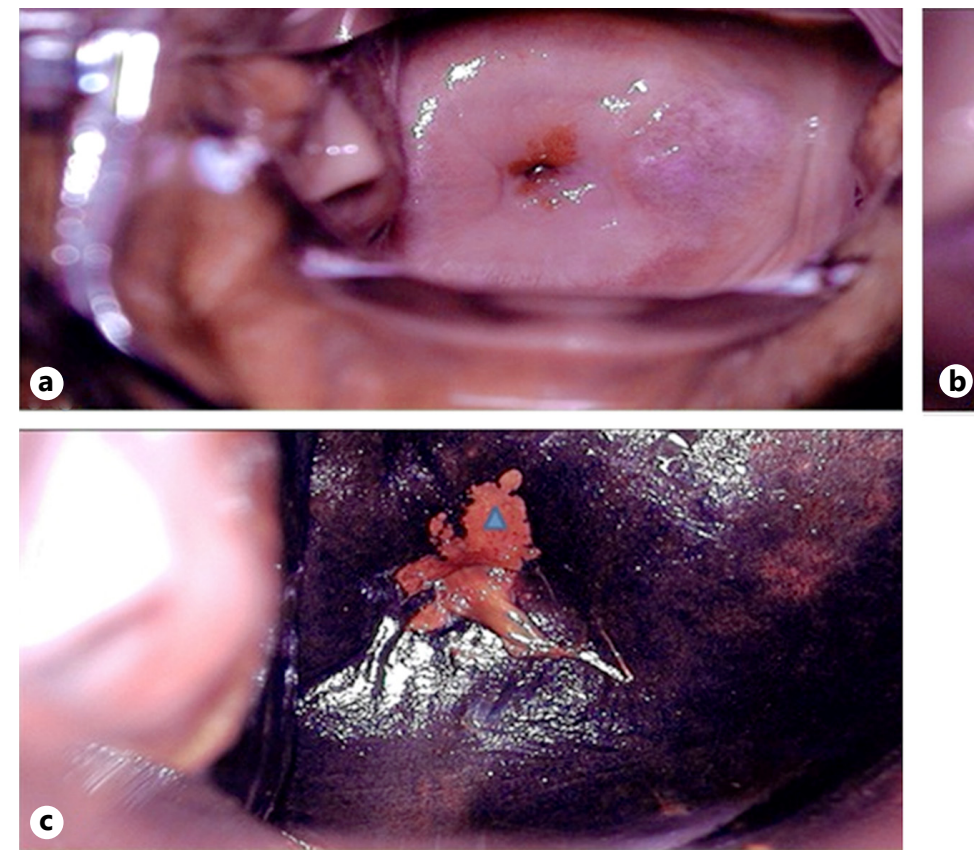

\section{Introduction}

Newly developed molecular techniques have allowed discovering more than 170 human papillomaviruses (HPV) genotypes [1]. These viruses are implicated in cutaneous or mucosal lesions responsible for $4.8 \%$ of cancer worldwide [2]. HPV genotypes are divided into "highrisks" HPV responsible for HPV-induced cancers justifying a systematic screening and low-risk HPVs responsible for warts, papilloma, and low-grade squamous intraepithelial lesions (L-SIL) [1].

Inherited chromosomally integrated human herpesvirus type 6 (iciHHV-6) is rare and defined as when viral genome from HHV6 is integrated into the host germ line genome [3]. A positive polymerase chain reaction in nail and hair follicles allow us to distinguish infection by HHV6 and iciHHV-6 [3]. Spontaneous reactivation from iciHHV-6A was already observed in an immunosuppressed pediatric patient or after using valproate acid and carbamazepine [4].

We report here an atypical case of Vaginal Intra-epithelial Neoplasia (VaIN) grade 2 due to a low-risk HPV4 associated in a woman with an iciHHV-6A.

Fig. 1. Macroscopic aspect of the colposcopy. a Colposcopic aspect without preparation. b Colposcopic aspect after acetic acid application. c Aspect after lugol application. Star indicates the squamous junction area. Triangle indicates the iodopositive area. 

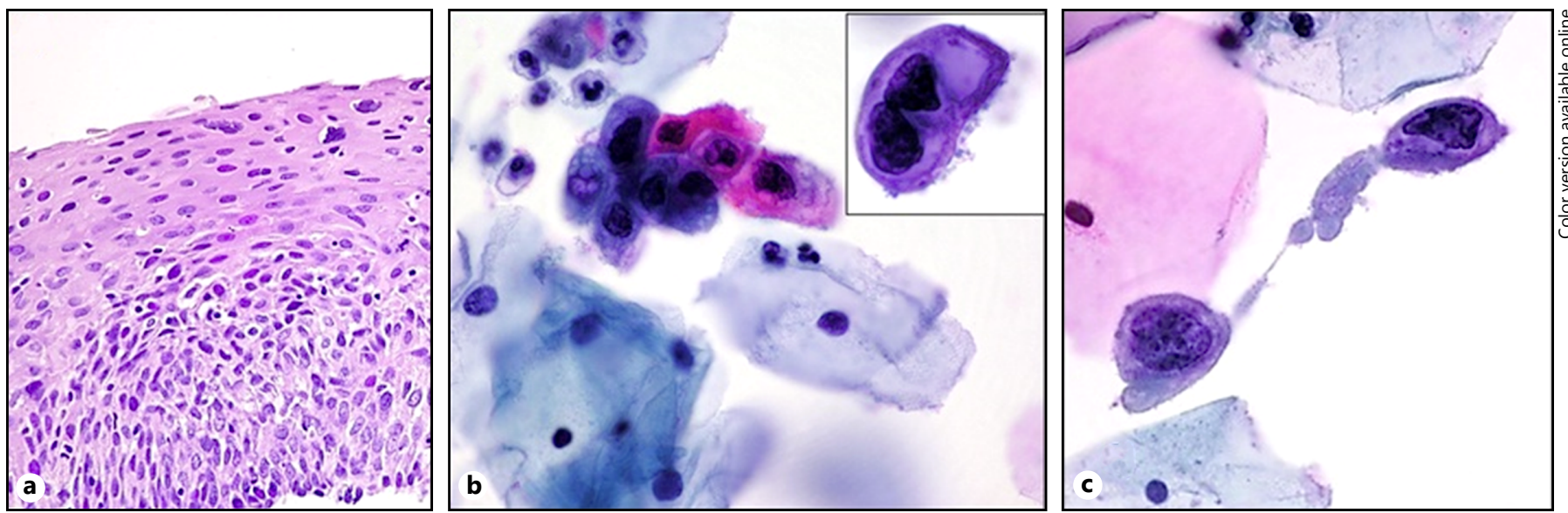

Fig. 2. Microscopic aspect of suspected neoplasia. a X400 VaIN2 aspect: chorionic inflammation associated with infiltration by lymphocytes and plasmocytes. The epithelial structure was modi-

fied on $1 / 3$ to $1 / 2$ of its length. b X1.000 Koïlocytes aspect: small dichromic basal cells with hyper chromatic nuclei. c X1.000 H-SIL aspect: small basal cells with irregular nuclei and cytoplasm.

Table 1. Patient's immunity exploration

a Cellular and humoral immunity exploration. Analyses were performed on April - May 2015 on Cell-Dyn(r) Sapphire system (Abbott, USA), FC500 ${ }^{\circledR}$ (Beckman Coulter, Switzerland) and Hydrasys(r) (Sebia, France). No abnormalities were found on cellular quantification of leukocytes and lymphocytes and on quantification of immunoglobulins.

\begin{tabular}{|c|c|c|c|c|c|c|c|}
\hline & $\begin{array}{l}\text { Neutrophils, } \\
\text { G/L }\end{array}$ & $\begin{array}{l}\text { Lymphocytes, } \\
\text { G/L }\end{array}$ & $\mathrm{T} 4+, \%$ & $\mathrm{~T} 8+, \%$ & $\operatorname{IgG}, \mathrm{g} / \mathrm{L}$ & IgM, g/L & Phoresis \\
\hline Results & 3.61 & 2.01 & 52.36 & 15.47 & 8.29 & 0.78 & Normal \\
\hline Norm & $1.5-8$ & $1.5-6.5$ & $31-63$ & $12-37$ & $7-16$ & $0.4-2.8$ & - \\
\hline
\end{tabular}

G/L, giga per liter; T4+, TCD4+ cells; T8+, TCD8+ cells; IgG, immunoglobulin G; IgM, immunoglobulin M.

b Serological status of main viral infections. Analyses were performed using Liason ${ }^{\circledR}$ XL (DiaSorin, Italy).

\begin{tabular}{lllllllll}
\hline & HSV 1-2 & CMV & EBV & HHV-6 & PVB19 & Measles virus & Mumps virus & Rubella virus \\
\hline IgG & + & + & $+^{*}$ & + & + & + & + & + \\
IgM & - & - & - & - & - & - & - & NP \\
\hline
\end{tabular}

NP, non-performed.

* IgG are positive against VCA and EBNA for EBV serology.

\section{Case Report}

A 54-year-old woman under hormone replacement therapy, showed during systematic monitoring in 2002 cervical lesions classified as L-SIL. In 2008, an aggravation of the cytological aspect was found during monitoring justifying a colposcopy examination. An L-SIL at microscopic scale was found without abnormalities at macroscopic scale. No koïlocytes, cellular reflects of the cytopathogenic effect caused by HPV infection, were observed during the pathologist's examination. In 2010, koïlocytes were finally found.
In 2012, some lesions were classified as high-grade SIL, justifying exploration of the genital tract. During a complete vaginoscopy, multiple suspect vaginal lesions and a cervix macroscopically normal were biopsied (Fig. 1), but no abnormalities were found on the hysteroscopy. Pathologists diagnosed a VaIN grade 2 on the histopathological aspect of these biopsies, confirmed by an augmentation of P16 protein expression and of the proliferation index (Ki67) (Fig. 2a). Koïlocytes were found on all samples (Fig. 2b, c). During all the clinical course (10 years) the search for infection by 35 HPV types (CLART2, Genomica, Madrid, Spain) remained 
negative even on samples with koïlocytes. Loop excision of the transformation zone and surgery were performed leading to the complete disappearance of infection and malignancy criteria. The patient is still closely monitored, but no sign of lesion has been observed so far.

All biopsies were retrospectively analyzed, by the International Agency for Research on Cancer that performed an extensive HPV screening panel (Luminex, TX, USA) ( $n=105$ genotypes). HPV-4 was found positive just above the detection threshold. Systematic Herpesviridae screening panel (Luminex, TX, USA) found a high but not quantifiable amount of HHV-6A DNA. A Polyomaviridae panel (Luminex, TX, USA) remained entirely negative.

Immunity was explored as well as the complete serological status for viral infections. No decrease of leukocytes or lymphocytes was found (Cell-Dyn ${ }^{\circledR}$ Sapphire system, Abbott, USA) and quantification for the CD4+ and CD8+ T cells were normal $\left(\mathrm{FC} 500^{\circledR}\right.$, Beckman Coulter, Swiss; Table 1a). Electrophoresis of immunoglobulins (Hydrasys(r), Sebia, France) was normal. The patient was seropositive for HHV-6 as for HSV-1, HSV-2, EBV, Measles, Mumps, rubella viruses and ParvovirusB19 (Liason ${ }^{\circledR}$ XL, DiaSorin, Italy) and seronegative for HIV (Table 1b).

HHV-6 quantification was performed on hair follicles and nail and blood samples and it showed a high HHV-6 viral load (6.73, 6.67 , and $6.62 \log _{10}$ copies $/ 10^{6}$-cells, respectively), confirming the presence of iciHHV-6A.

\section{Discussion}

This atypical course of a low-grade lesion diagnosed during a systematic monitoring finally revealed a VaIN grade 2 . This case is the first describing the association of an infection by a low-risk HPV and iciHHV-6A during the development of high-grade neoplasia in a female genital tract.

Although HPV-4 is known to be the sixth cause of benign cutaneous lesion or pre-cancer state, it is not known to be associated with high-grade mucosal neoplasia, especially in immune patients $[1,5]$.

Explorations of the biopsies demonstrated a non-expected high load of HHV-6A, which may be responsible for neurological disease (tropism for oligodendrocytes) or immune system alteration (tropism for T-lymphocytes and NK cells) $[6,7]$.

In this case, the association of HPV -4 and iciHHV-6A in the cell could be responsible for a synergistic effect leading to severe cellular abnormalities. Previous studies suggested that iciHHV- 6 could help the development of another viral infection by the modification of cellular receptor expression or pathways leading to possible predisposition to neoplasia [6]. Other studies, using a mice model, showed that HHV-6 could be an oncogenic virus by itself [8].

Without a specific treatment plan, patients with iciHHV-6 need to be intensively surveyed to optimize clinical management of suspect lesions at an early time of the disease before it progresses into the cancer state.

\section{Disclosure Statement}

Authors have no conflicts of interest to disclose.

\section{Ethics Statement}

For the purpose of this study, patient confidentiality was strictly maintained. This study was approved by the Ethical Committee of Hospices Civils de Lyon. Patient's approval has been searched, obtained, and then transmitted to the editorial board of the journal.

\section{References}

1 Maver PJ, Kocjan BJ, Seme K, Poljak M: Genomic diversity of low-risk human papillomavirus genotypes HPV 40, HPV 42, HPV 43, and HPV 44. J Med Virol 2014;86:272282.

2 Muñoz N, Bosch FX, de Sanjosé S, Herrero R, Castellsagué X, Shah KV, et al: Epidemiologic classification of human papillomavirus types associated with cervical cancer. $\mathrm{N}$ Engl J Med 2003;348:518-527.

3 Agut H, Bonnafous P, Gautheret-Dejean A: Update on infections with human herpesvi- ruses $6 \mathrm{~A}, 6 \mathrm{~B}$, and 7. Med Mal Infect 2017;47: 83-91.

4 Mardivirin L, Descamps V, Lacroix A, Delebassée S, Ranger-Rogez S: Early effects of drugs responsible for DRESS on HHV-6 replication in vitro. J Clin Virol 2009;46:300-302.

5 Grussendorf-Conen EI, Gissmann L, Hölters $\mathrm{J}$ : Correlation between content of viral DNA and evidence of mature virus particles in HPV-1, HPV-4, and HPV-6 induced virus acanthomata. J Invest Dermatol 1983;81:511513.
6 Lusso P, Malnati MS, Garzino-Demo A, Crowley RW, Long EO, Gallo RC: Infection of natural killer cells by human herpesvirus 6 . Nature 1993;362:458-462.

7 Alvarez-Lafuente R, De las Heras V, Bartolomé M, Picazo JJ, Arroyo R: Relapsing-remitting multiple sclerosis and human herpesvirus 6 active infection. Arch Neurol 2004;61: 1523-1527.

8 Razzaque A: Oncogenic potential of human herpesvirus-6 DNA. Oncogene 1990;5:13651370. 